\title{
LAWSON WILKINS PEDIATRIC ENDOCRINE SOCIETY
}

SAN FRANCISCO HILTON HOTEL

Tuesday, May 1, 1984

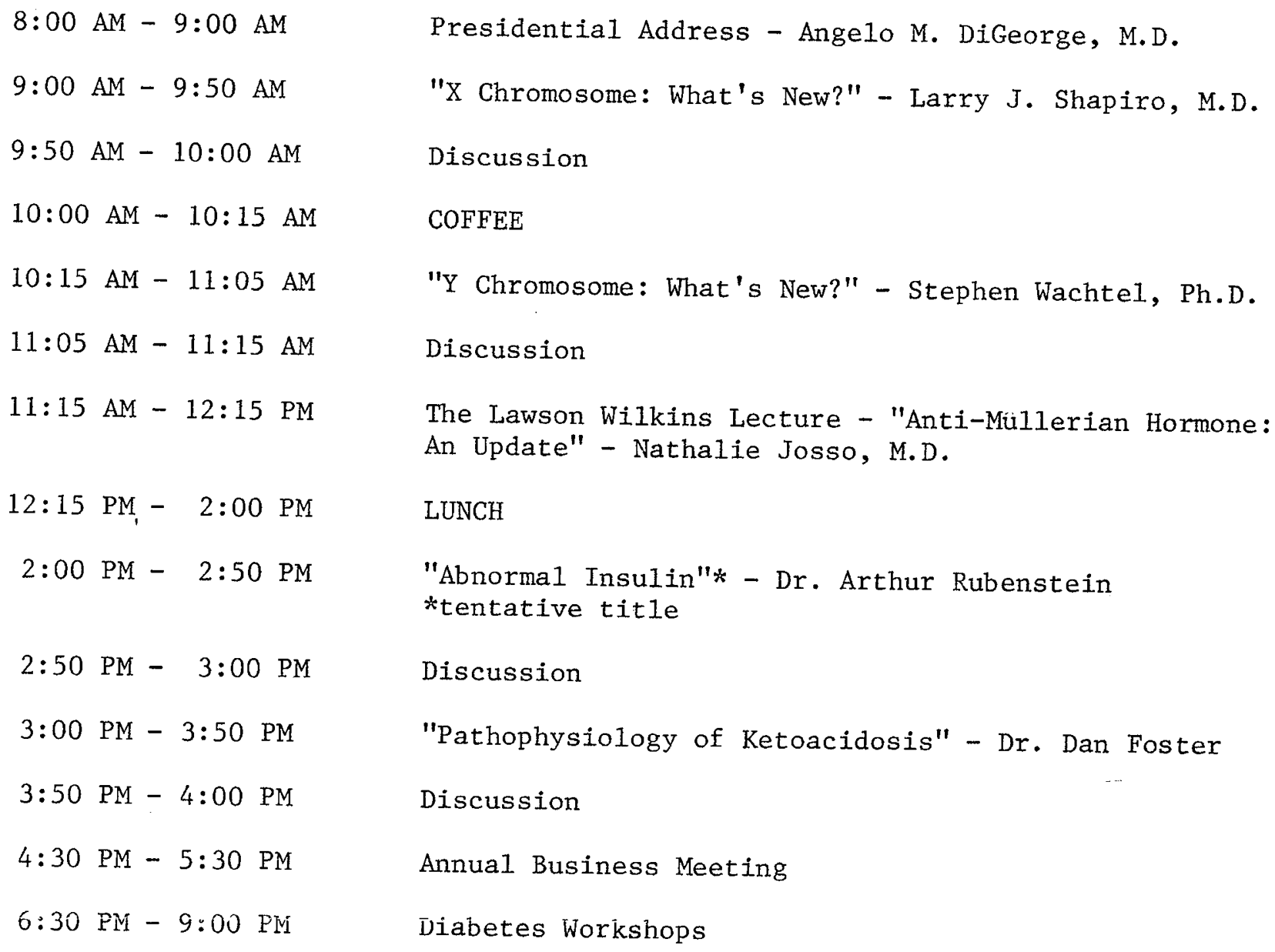

